\title{
A NOTE ON GENERALIZED HERONIAN MEANS
}

\author{
WALTHER JANOUS
}

Abstract. In this note several inqualities for generalized Heronian Means of two numbers are proved. These means are defined for the first time in this paper and they are compared with some well-known means. All inequalities are best possible.

Mathematics subject classification (2000): 26D20, 26E60.

Key words and phrases: Generalized Heronian means, arithmetic mean, geometric mean, power means, identric mean.

\section{REFERENCES}

[1] H. Alzer And W. Janous, Solution of Problem 8* , Crux. math. 13 (1987), 173-178.

[2] P. S. Bullen, D. S. Mitrinović AND P. M. Vasić, Means and Their Inequalities, Dordrecht, 1988.

[3] M. QIJI, Dual Mean, Logarithmic and Heronian Dual Mean of Two Positive Numbers (in Chinese), J. Suzhou Coll. Educ. 16 (1999), 82-85.

[4] H.-J. SEIFFERT, Ungleichungen für elementare Mittelwerte, Arch. Math. (Basel) 64 (1995), 129-131. 